\title{
Preferences or blocs? Voting in the United Nations Human Rights Council
}

\author{
Simon Hug • Richard Lukács
}

Published online: 20 July 2013

(C) Springer Science+Business Media New York 2013

\begin{abstract}
After four years in operation the United Nations Human Rights Council (UNHRC) is subject to criticism, and various scholars and practitioners alike present and discuss reform proposals. In the present paper we study systematically the controversial decisions in the UNHRC. We find that controversial proposals are introduced by countries with a blemished human rights record, and that in the votes on these proposals the council members belonging to the European Union (EU) vote very distinctly from the remaining members and have preferences quite different from those member states that violate human rights. Extending an empirical approach frequently used in parliamentary research we can also show that in votes in the UNHRC preferences of member states dominate over their membership to particular blocs. As controversial votes also heavily polarize the UNHRC we argue that the problems faced by the UNHRC's predecessor, namely the Commission on Human Rights, have reappeared.
\end{abstract}

Electronic supplementary material The online version of this article (doi:10.1007/s11558-0139172-2) contains supplementary material, which is available to authorized users.

This paper draws in part on a seminar paper and the master's thesis by Richard Lukács (2010, 2011). An earlier version was presented at the 4th Conference on "The Political Economy of International Organizations" (Zürich, January, 2011). Very helpful comments by the discussants Niklas Potrafke and James Vreeland, as well as by Gary Goertz, Laurent Graf, the anonymous reviewers and the editor, research assistance by Simone Wegmann and partial financial support by the Swiss National Science Foundation (Grant-No 100012-129737) is gratefully acknowledged.

S. Hug $(\bowtie) \cdot$ R. Lukács

Département de Science Politique et Relations Internationales,

Faculté des Sciences Économiques et sociales,

Université de Genève,

40 Bd du Pont d'Arve, 1211 Genève 4, Switzerland

e-mail: simon.hug@unige.ch

R. Lukács

e-mail: richard.lukacs@gmail.com 
Keywords Human rights $\cdot \mathrm{IO} \cdot$ United Nations · Voting

JEL Classification F53 - F55

\section{Introduction}

From its very inception in 2006 the United Nations Human Rights Council (UNHRC) attracted its fair share of criticism. The assessment by former United States Ambassador to the United Nations (UN) John Bolton was clearly the most colorful: "We want a butterfly. We're not going to put lipstick on a caterpillar and call it a success". ${ }^{1}$ After operating for four years as the successor of the even more vigorously decried Commission on Human Rights (UNCHR) the United Nation considers reforming this new body of the $\mathrm{UN}^{2}{ }^{2}$ So far, however, no systematic studies exist to our knowledge elucidating how the UNHRC operates during its regular sessions (three per year). ${ }^{3}$

In the present paper we wish to contribute to filling this gap by offering a systematic study of the controversial votes that have taken place in the first thirteen sessions between 2006 and 2010 in the UNHRC. While a large majority of all resolutions are adopted without opposition or only abstentions, 70 votes between 2006 and 2010, however, revealed clear divergences of opinion with some countries opposing the proposal. In analyzing these votes we draw on the one hand on the literature on voting in international assemblies and on the other on recent work on parliaments in general. While the former literature has strongly emphasized bloc-voting, i.e., countries belonging to particular groups voting together, the latter suggests that when analyzing such groups (e.g., parties) one cannot neglect the role preferences play. Drawing on an empirical approach having become prevalent in parliamentary research we can show that the two blocs commonly assumed to be important in the UNHRC influence less strongly voting in this assembly than variables assumed to relate with the underlying preferences of states. Extending this analysis we can also show that countries with blemished human rights records are most frequently the authors of controversial proposals. The latter often pass against the council members of the European Union (EU), who in these votes adopt very distinct voting patterns. Analyzing more in detail how the identity of the proposer affects voting behavior we find clear patterns that these divisive votes play a considerable role in polarizing the UNHRC.

The remainder of the paper is organized as follows. In the next section we briefly present the development of human rights in the context of the United Nations as it led to the creation of the UNHRC in 2006. Section 3 discusses the insights scholars

\footnotetext{
1 “Apologise or we'll cut your funding, US envoy tells the UN" The Times, June 9, 2006 (see also Rajagopal 2007).

${ }^{2}$ Brett D. Schaefer "Elections for U.N. Human Rights Council Underscore the Need for Reform" Backgrounder. No. 2417 June 2, 2010. Published by the Heritage Foundation and "Le Conseil des Droits de l'Homme sera revu" Le Temps Septembre 6, 2010 http://emploi.letemps.ch/Facet/print/Uuid/ 9018569c-b9bf-11df-9ea7-6791aedb1a60/Le_Conseil_des_Droits_de_lHomme_sera_revu.

${ }^{3}$ Partial exceptions are the studies by Cox (2010), Seligman (2011) and McMahon (2012), focusing on particular aspects of the new body. 
have gained by analyzing the voting behavior in other UN bodies, most notably the General Assembly (UNGA), which provides part of the theoretical backdrop for our study. ${ }^{4}$ Based on this literature we present three broad hypotheses on the way in which preferences and bloc membership, in conjunction with the proposer's identity, should affect voting behavior. In Section 4 we present our empirical strategy which relies on hierarchical item-response theory models that allow for a direct estimation of the relevant parameters of interest to us. In Section 5 we present our empirical results before concluding in Section 6.

\section{Human rights and the human rights council}

Following World War II human rights have become a mainstay in international relations. The devastation by the War with the numerous atrocities and the continuous violations of international rules and norms called for a new governing body after the failure of the League of Nations. The creation of the UN in 1945 was the first step toward the increased importance of human rights. Soon thereafter, in 1946, the UN created a sub-body which would deal with the promotion of human rights, namely the Commission on Human Rights (UNCHR) (for an overview, see Tolley 1987). In 1948 the Universal Declaration of Human Rights (UDHR) was adopted with 48 yes and 8 abstentions in the UN General Assembly (UNGA) (Simmons 2009, 41). The UDHR applies to all people, but on its own is not a binding legal document in international law (Simmons 2009, 42). To ensure that the provisions set forth in the UDHR would be applied, the UNGA worked out the two additional International Covenants on Human Rights (1966) and the Optional Protocol, which are legally binding documents, and as a consequence can be enforced in courts (Simmons 2009, 46ff). Nonetheless, it is the UDHR that is widely cited when it comes to human rights, and it has become one of the foundations of our understanding of modern human rights. On the basis of these legal documents the international community set out countless conventions in various fields of human rights, sometimes in the framework of international conferences and initiatives, sometimes within the UNCHR (e.g., Carey et al. 2010).

Regardless of the UNCHR's success with introducing the Universal Declaration of Human Rights of 1948, the UNCHR became over the decades a forum that was too heavily exposed to political influence (e.g., Edwards et al. 2008). It was referred to as the "shame of the UN" by outsiders as well as by insiders such as the former Secretary General Kofi Annan. The latter stated in his special report entitled "In Larger Freedom" that the Commission was "undermined by the politicization of its sessions and the selectivity of its work"6 and that "the Commission's capacity to perform its tasks has been increasingly undermined by its declining credibility and

\footnotetext{
${ }^{4}$ Other studies focus on international bodies like the European parliament (e.g., Attina 1990; Brzinski 1995; Hix et al. 2006), the assembly of the International Labor Organization (e.g., Boockmann 2006, 2003) or the United Nations Security Council (UNSC) (e.g., O’Neill 1996; Dreher et al. 2009).

${ }^{5}$ Editorial "The Shame of the UN" The New York Times, February 26, 2006. http://www.nytimes.com/ 2006/02/26/opinion/26sun2.html.

${ }^{6}$ UN Special Report 2005. In Larger Freedom Addendum http://www.un.org/largerfreedom/add1.htm.
} 
professionalism."7 The report also emphasizes the possible reputational damage of the Commission to the UN as a whole since "the credibility of the Human Rights Commission has eroded to the point that it has become a blot on the reputation of the larger institution." 8 This report would later guide the reforms of the Commission. Others, such as the US ambassador to the Commission at the time, called the election of countries with a poor human rights record just "absurd." 9 Secretary General Kofi Annan even stated that, "[s]tates have sought membership of the Commission not to strengthen human rights but to protect themselves against criticism or to criticize others."10

Edwards et al. $(2008,394)$ find in their study that members could have had several reasons for joining the Commission, namely to "influence the agenda to blame other states..., in an act of self-defense, enabling them to insulate themselves from investigation... and to deflect attention from themselves." In addition, developing countries tried to shift the focus from civil and political toward economic rights. As history has shown, this is not uncommon within the UN framework as the interpretation and focus on human rights can be very diverse. Edwards et al. (2008) even find that countries with a poor human rights record had higher chances of getting elected to the Commission than those with high human rights standards. ${ }^{11}$

All this criticism was not in vein and following the publication of the UN Special Report the General Assembly decided ${ }^{12}$ to abolish the Commission and replace it by the UNHRC in March 2006. The newly created Council reports directly to the General Assembly and therefore has a higher status than the Commission. It defines itself as "an intergovernmental body within the UN system made up of 47 States responsible for strengthening the promotion and protection of human rights around the globe." 13 These 47 Member States are elected for a three year term by the UNGA in accordance with the members' "contribution to the promotion and protection of human rights and their voluntary pledges and commitments made thereto" and "shall uphold the highest standards in the promotion and protection of human rights."14 According to Cox (2010, 89ff), however, especially when considering the much more

\footnotetext{
${ }^{7}$ UN Special Report 2005. In Larger Freedom http://daccess-dds-ny.un.org/doc/UNDOC/GEN/N05/270/ 78/PDF/N0527078.pdf?OpenElement, p. 45.

${ }^{8}$ UN Special Report 2005. In Larger Freedom Addendum, 5 http://www.un.org/largerfreedom/add1.htm.

9"Sudan's U.N. post provokes anger" Seattle Times, May 5, 2004 http://seattletimes.nwsource.com/ html/nationworld/2001920167_sudan05.html. See also the position of Human Rights Watch on this issue in the Press Release Democracy Coalition Project 2004. http://www.democracycaucus.net/pdf/ undc_press_release_may04.pdf.

${ }^{10}$ UN Special Report 2005. In Larger Freedom Addendum http://www.un.org/largerfreedom/add1.htm, p. 45.

${ }^{11}$ See also Brett D. Schaefer "Elections for U.N. Human Rights Council Underscore the Need for Reform" Backgrounder. No. 2417 June 2, 2010. Published by the Heritage Foundation.

${ }^{12}$ Resolution UN/A/RES/60/251 http://www2.ohchr.org/english/bodies/hrcouncil/docs/A.RES.60.251_En. pdf.

${ }^{13} \mathrm{http} / / / \mathrm{www} 2$. ohchr.org/english/bodies/hrcouncil.

${ }^{14}$ United Nations 2006. A/Res/60/251 http://www2.ohchr.org/english/bodies/hrcouncil/docs/A.RES.60. 251_En.pdf.
} 
far-reaching reform proposal by the United States, the changes introduced regarding the membership are rather negligible. While members of the UNCHR were elected by the ECOSOC committee of the UNGA, the regional groups still play a central role in the election process. ${ }^{15}$ Nevertheless, Cox $(2010,108)$ notes that the share of countries that are considered as not free by Freedom House slightly dropped among the members in the first sessions of the UNHRC compared to the last sessions of the UNCHR. ${ }^{16}$ More substantial changes concerned the Council's working mechanisms, which include the following: ${ }^{17}$

1. The Universal Periodic Review, "which serves to assess the human rights situations in all United Nations Member States."

2. An Advisory Committee "which serves as the Council's 'think tank' providing it with expertise and advice on thematic human rights issues and the Complaint Procedure which allows individuals and organizations to bring human rights violations to the attention of the Council."

3. "The Human Rights Council also works with the UN Special Procedures established by the former Commission on Human Rights and now assumed by the Council."

\section{Voting in international organizations and human rights}

While voting in the UNHRC has to our knowledge not been studied systematically (see for some discussion and partial exceptions Besant \& Malo 2009; Cox 2010; Seligman 2011; McMahon 2012), some scholars have looked under various perspectives at voting in its predecessor, i.e., the Human Rights Commission (e.g., Smith 2006; Lebovic and Voeten 2006 see below). Much more detailed studies on voting in international bodies focused on the UNGA. Early studies relied heavily on the notion of "blocs," which were assumed to emerge in the voting record. Studying possible bloc building appeared to be important as it can suggest the direction which

\footnotetext{
${ }^{15}$ In order to have systematic rotation within the Council, certain countries were elected only for one or two year terms in 2006. This has had the effect that by April 201064 UN member states had been elected to the Council. Countries are elected depending on geographical distribution, the so-called UN regional groups. These groups are the following (numbers of members in the Council in parentheses): Group of African States (13); Group of Asian States (13); Group of Eastern European States (6); Group of Latin American and Caribbean States (8); Group of Western European and other States (7).

${ }^{16}$ Strictly speaking, these selection mechanisms are likely to influence the working of the UNHRC, and thus also its voting process. We refrain from addressing this issue in this paper directly for three reasons. First, as we focus in our analysis on how characteristics of UNHRC members influence their voting records in controversial resolutions, and the latter can be introduced even by nonmembers, we believe that taking into account the membership selection would not affect our analyses. Second, our analyses do not pretend to offer more general insights about decisions on human rights in international bodies. We only wish to show what influences the voting decisions of members of the UNHRC. Third, as our analyses indirectly allow for whether the politicization in the UNHRC is lower than in the UNCHR, the fact that membership rules have only slightly changed allows us to keep these constant. This even more so as the election of members proposed by regional groups is almost systematically endorsed by the UNGA.

${ }^{17}$ http://www.ohchr.org/EN/HRBodies/HRC/Pages/AboutCouncil.aspx.
} 
an assembly may take and suggest ideas about voluntary or involuntary cooperation and coordination among countries on specific topics. The notion of blocs proved, however, difficult to define. Hovet (1960) offers a comprehensive discussion of this notion, while Lijphart (1963) criticizes the various attempts to rely on geographical groups as defined in the Charter itself, geographical proximity, closeness in other respects etc. in earlier work (e.g., Ball 1951; Furey 1954; Riggs 1958; Ogley 1961; Nicholas 1962).

While differing, these various early definitions have nonetheless some blocs in common, like the Soviet Union with its satellite states (also called the Soviet-bloc), the African bloc (sometimes mixed with the Arabs), the Arabs, the Latin American bloc (Lijphart 1963), and later also the Western countries. Newer studies covering longer time periods (e.g., Holloway 1990), argue that the developing countries or also the "Muslims"18 appeared as new blocs, but also the "imperialists" or the "neutrals" (Newcombe et al. 1970), depending on the factors analyzed. Holloway (1990) shows, however, that depending on the time period studied the blocs are not located constantly in the same place spatially speaking. Certain countries moved around in this space, so the "shapes" of the blocs have also been changing. Apart from studies focusing on how the different blocs are taking form, others explore the internal life of the blocs themselves. For example some authors study whether there are blocs within the blocs (for the African "bloc inside the bloc" see Meyers 1966). ${ }^{19}$

With the end of the Cold War, the long established Warsaw Pact group (Soviet-bloc), often considered as the most cohesive bloc, disappeared at least in theory. In the 1990s the European Union (EU) appeared as an important new bloc (analyzed by, among others, Young and Rees 2005; Smith 2006; Luif and Radeva 2007).

The way in which these blocs are identified, however, is largely inductive. More specifically, authors most often employ some sort of a scaling approach to represent countries in a low-dimensional policy space based on their voting records. Clusters of countries are then identified on the basis of notions of blocs favored by the authors. Proceeding this way, however, allows not to distinguish two possible ways in which such clusters might emerge. ${ }^{20}$ On the one hand it might be that a group of countries, for instance the member-states of the European Union (see below) wish to coordinate their stance on human rights issues. This should lead to a more cohesive and distinct voting pattern of these member states. On the other hand these same member states might vote more often together simply because they have similar preferences when it comes to resolutions on human rights. In what follows, drawing on an empirical strategy employed in parliamentary research, we propose a way to separate out these two elements, while also considering the role the proposers of controversial resolutions play in explaining voting patterns.

\footnotetext{
${ }^{18}$ One could maybe argue that in the 1950 s and 1960 s when referred to the Arabs, the Muslims were also included.

${ }^{19}$ See also the study by Marin-Bosch (1987).

${ }^{20} \mathrm{We}$ consider this problem to be akin to the issue in research on parliaments whether members of the same party vote together because they have the same political preferences or because belonging to a particular party influences their voting record (see most notably Krehbiel 1993).
} 


\subsection{Voting in the UNHRC: Expectations}

In the most comprehensive study of the UNGA, Voeten $(2000,191)$ argues that voting heavily clusters member states and thus classifies various groups of countries assumed to appear in UNGA voting. Similarly, two recent studies focusing more closely on human rights issues in the UN implicitly or explicitly rely on the idea of "blocs." Smith (2006) assesses directly how one specific group of countries, namely the member states of the European Union (EU), behaves in votes in the third committee of the UNGA (dedicated to human rights issues) and the UNCHR. As Smith (2006) argues the EU puts considerable emphasis on appearing united in human rights issues on the international scene (see also Wouters et al. 2008). Despite this emphasis, she finds considerable dissent in the votes she analyzes. Lebovic and Voeten (2006) offer a more comprehensive study of voting in the UNCHR, finding that reputation effects appear to have played an increasing role over the lifetime of this commission. These authors subsequently show that condemnation of particular countries by the UNCHR affect multilateral (though not bilateral) aid flows (Lebovic and Voeten 2009).

Boockmann and Dreher (2011) study voting on human rights issues in the UNGA and argue that the average level of human rights violations in a country's "peer group" dominates the individual human rights record of a country in affecting the latter's voting decisions. While this seems an interesting empirical result, given that the "peer groups" are defined by the World Bank classification it is hard to make sense out of this finding in terms of a causal mechanism.

The two only systematic studies focusing on voting in the UNHRC that we are aware of focus on specific aspects. Cox $(2010,111 \mathrm{ff})$ suggests that resolutions targeting particular countries (most notably Israel) are as prevalent in the new body as they were in its predecessor. This assessment is confirmed by Seligman (2011) who also proposes to evaluate three broad hypotheses by comparing the voting behavior of groups identified by their degree of political freedoms as measured by Freedom House in resolutions voted upon in the first sessions of the UNHRC. He finds very distinct voting patterns especially for resolutions targeting Israel. ${ }^{21}$

These studies suggest, as does the broader literature on voting in international assemblies, that at least two elements should influence voting in a body like the UNHRC. On the one hand, studies like those by Voeten (2000), Smith (2006), Wouters et al. (2008) and Boockmann and Dreher (2011) suggest that belonging to particular groups of countries or blocs (defined in whatever way) should influence the way in which UNHRC member states vote. On the other hand, authors like Lebovic and Voeten (2009) and Seligman (2011) suggest that factors more related to the preferences of states should affect the voting behavior. Consequently, we propose two very broad hypotheses that rely on the arguments discussed above:

H1: Belonging to a group of countries taking clear positions on human rights affects the voting behavior of its member-states (in a more human rights respecting way, respectively in the opposite direction).

\footnotetext{
${ }^{21}$ Relatedly McMahon (2012) offers a systematic analysis of the "universal periodic review."
} 
H2: A country's preferences in the area of human rights records affect its voting behavior.

To empirically evaluate these two hypotheses we need on the one hand to identify the groups of countries taking stances on human rights issues, and on the other identify variables that should be related to the countries' preferences in the area of human rights. Regarding the first issue, we argue that the EU and the Organization of the Islamic Conference (OIC, founded in 1969) ${ }^{22}$ are the blocs that take most often the clearest stances. Regarding the EU, the studies by Smith (2006) and Wouters et al. (2008) amongst many others underline the importance the EU attributes to human rights, especially as they are discussed in international bodies. Thus, Macaj and Koops (2012, e.g., 72) discuss in detail how the EU's Common Foreign and Security Policy has led to an important coordination effort in the area of human rights. Regarding the OIC, Besant and Malo $(2009,145)$ note the importance of this group (see also Lukács 2010, 2011), ${ }^{23}$ while Steinberg $(2012,374)$ goes as far as stating that OIC plays a dominating role in the UNHRC (for a similar point, see Smith 2010, 225). As Macaj and Koops $(2012,81)$ argue, this is related to the growing importance of the notion of "defamation of religion." In this debate the OIC plays clearly a dominant role. Thus, if any blocs should constrain the voting behavior of UNHRC member states the EU and the OIC should certainly be among them.

In order to separate out the effect of preferences from the one exerted by blocmembership we also need to identify variables likely to be related to the underlying preferences of states in the area of human rights. Based on the literature, we argue that three variables can serve as proxies for these preferences. First, as several studies have argued, the respect for human rights can be assumed to be akin to revealed preferences by states. Consequently we will rely on Cingranelli and Richards' (2010) data and for robustness tests on the "Political Terror Scale" (Wood and Gibney 2010). Second, as numerous studies have shown (e.g., Park 1987; Henderson 1991; Poe \& Tate 1994; Hathaway 2002; Neumayer 2005; Vreeland 2008) democracies have on average a better respect of human rights. Consequently, we assume that being a democracy will also relate to preferences important in votes on human rights issues. ${ }^{24}$ Finally, we also consider that ratifying treaties in the area of human rights should be related to preferences in this area. Several scholars have demonstrated that signing and ratifying treaties and conventions in this area is related to respect for human rights but not necessarily in a straightforward way (see Hathaway 2007; Vreeland 2008; Simmons 2009; Hollyer \& Rosendorff 2011).

While the primary focus of this paper is to assess what affects the voting patterns (and/or revealed ideal-points), we also wish to take into account how the

\footnotetext{
${ }^{22}$ The OIC serves as "collective voice of the Muslim world and ensuring to safeguard and protect the interests of the Muslim world in the spirit of promoting international peace and harmony among various people of the world" (Source: http://www.oic-oci.org/page_detail.asp?p_id=52).

${ }^{23}$ Simmons $(2009,83 f)$ finds that Muslim countries do not strongly differ from those of other cultures when it comes to ratifying human rights treaties, except those relating to women's rights.

${ }^{24}$ See for a related, more theoretically grounded argument Hillman and Potrafke (2011).
} 
authorship of a proposal affects these patterns. We do this for two reasons. First of all, several studies have highlighted that agenda-setting is closely related to voting behavior (see for instance Carrubba et al. 2008). Second, and relatedly, not all decisions in the UNHRC are reached in votes. A series of resolutions and other decisions are adopted without a vote. Consequently, the observed votes and the members' voting behavior in the UNHRC can be considered as roll call votes, as at least one member wishes to make the voting result public. As Hug (2010) shows, such votes often differ regarding several characteristics from secret votes. Carrubba et al. (2008) derive from a theoretical model, however, the insight that the content of the proposal plays in this context a central role.

Consequently, in our analyses we also control for the authorship of the proposal to account at least in part for the possible selection biases identified by Hug (2010). ${ }^{25}$ As will become apparent below, the authorship of controversial proposals is heavily concentrated among a small set of countries. We expect that resolutions proposed by countries with rather extreme views in the area of human rights will polarize more strongly the UNHRC member states. Hence we will also evaluate whether countries frequently submitting controversial resolutions lead to a polarization of voting in the UNHCR:

H3: Resolutions submitted by countries with less respect for human rights polarize the voting behavior in the UNHCR.

As we show below, four sets of countries have submitted the largest share of controversial votes, namely Cuba, Egypt, Pakistan and member states of the EU. Consequently, we will test this third hypothesis by assessing how polarizing resolutions proposed by these four groups compare to all the other resolutions.

\section{Data and model}

In this section we briefly describe the data we employ before discussing in more detail the empirical model used to test our hypotheses.

\subsection{Data}

The data employed for this study consists of the recorded votes of the UNHRC's first thirteen ordinary sessions as of April 2010. ${ }^{26}$ Overall the UNHRC reached 271

\footnotetext{
${ }^{25}$ We do not go beyond this partial fix of the problem, as to our knowledge, there does not exist a selection model that deals with the empirical approach we need to adopt here (see below).

${ }^{26}$ We refrain from comparing explicitly voting in the UNHRC with voting in its predecessor (the UNCRH), as despite some similarities (see above) they still differ in terms of membership and procedure (for an attempt in such a comparison, see Hug (2013)). For all documents concerning the voting see the UNHRC website.
} 
decisions on resolutions during the first thirteen sessions. ${ }^{27}$ The large part of resolutions were, however, adopted without votes. As for the analyses we will carry out below we will rely on votes and, in an even more constraining fashion on nonunanimous votes, it is important to understand what characterizes the resolutions that led to a vote. Table 1 reports for those 198 resolutions that were drafted and submitted by a single actor whether or not a vote occurred, its authorship and in how many sessions the proposer was member of the UNHRC. ${ }^{28}$

Table 1 first shows that only four countries drafted and submitted ten resolutions or more, namely Cuba, Egypt, France and Pakistan. Three of these countries had, according to Cingranelli and Richards' (2010) data, a rather blemished human rights record in $2008 .{ }^{29}$ Second, as about one fourth of all resolutions are adopted in votes and mostly with controversy, it is striking that the resolutions introduced by three of these countries (the exception is France) are more frequently submitted to a vote than the average. This is also the case for some other countries, but given the small numbers involved, these might be outliers. Obviously, the number of sessions in which Cuba (13), Egypt (13), France (11) and Pakistan (13) were members might also explain the high numbers of resolutions introduced by these countries. ${ }^{30}$ Several other countries were, however, member of the UNHRC for equal number of sessions and did not introduce as many resolutions, and certainly not as many controversial ones.

Looking more closely at Table 1 one notes that following the three top-ranked countries (Pakistan with 23 resolutions, Cuba with 20 and Egypt with seven) thirteen different countries proposed the remaining ones. Among these, seven stem from EU-member countries. ${ }^{31}$ As we will analyze how EU member countries vote in controversial votes, it is useful to assess how the EU fares in these 70 votes as a function of who proposed the resolution. As Table 2 nicely shows, whenever Cuba and to a lesser degree Pakistan or Egypt propose a resolution, the chances that the EU-member countries will be on the winning side are small or even minute. ${ }^{32}$

Thus, it is obvious that simply focusing on the decisions reached in votes in the UNHRC may introduce a bias, as they do not reflect the full business of the UNHRC (see for a more detailed analysis along these lines on the UNGA Hug 2012). Information on the individual voting records is, however, only available for

\footnotetext{
${ }^{27}$ UNHRC 2010. http://www2.ohchr.org/english/bodies/hrcouncil/.

${ }^{28}$ The remaining 73 resolutions were submitted by several countries or in the name of a group, and thus we omit these from Table 1. Glancing at these resolutions suggests that including them would not alter the picture presented in Table 1.

${ }^{29}$ See the "Political Terror Scale" (Wood and Gibney 2010) for a similar assessment.

${ }^{30}$ We refrain from calculating averages per membership session as resolutions can also be introduced by non members and the president.

${ }^{31}$ The EU countries are the following (with the number of resolutions in parentheses); Finland (1), Germany (2), Poland (1) Russia (1) Slovenia (1) Portugal (1), and Spain (1). The remaining countries are the following (with the number of resolutions in parenthesis); Algeria (4), Burkina Faso (1), Canada (1), Japan (1), Nicaragua (1) and South Africa (2).

${ }^{32}$ We determined the EU's position as being the modal response among "yea" and "nay" votes. Only if all EU member countries did abstain did we consider the vote as characterized by EU's abstention.
} 
Table 1 Drafters of resolutions adopted with and without votes

\begin{tabular}{|c|c|c|c|c|c|c|c|}
\hline \multirow[b]{2}{*}{ Country } & \multicolumn{2}{|c|}{ Adopted without vote } & \multicolumn{2}{|c|}{ Voted upon } & \multicolumn{2}{|c|}{ Total } & \multirow{2}{*}{$\begin{array}{l}\text { Membership } \\
\text { n sessions }\end{array}$} \\
\hline & $\mathrm{n}$ & $\%$ & $\mathrm{n}$ & $\%$ & $\mathrm{n}$ & $\%$ & \\
\hline Algeria & 2 & $50.0 \%$ & 2 & $50.0 \%$ & 4 & $100.0 \%$ & 5 \\
\hline Argentina & 3 & $100.0 \%$ & 0 & $0.0 \%$ & 3 & $100.0 \%$ & 10 \\
\hline Armenia & 2 & $100.0 \%$ & 0 & $0.0 \%$ & 2 & $100.0 \%$ & 0 \\
\hline Austria & 5 & $100.0 \%$ & 0 & $0.0 \%$ & 5 & $100.0 \%$ & 0 \\
\hline Azerbaijan & 2 & $100.0 \%$ & 0 & $0.0 \%$ & 2 & $100.0 \%$ & 11 \\
\hline Bolivia & 2 & $100.0 \%$ & 0 & $0.0 \%$ & 2 & $100.0 \%$ & 8 \\
\hline Brazil & 7 & $100.0 \%$ & 0 & $0.0 \%$ & 7 & $100.0 \%$ & 13 \\
\hline Burundi & 1 & $100.0 \%$ & 0 & $0.0 \%$ & 1 & $100.0 \%$ & 0 \\
\hline Canada & 5 & $83.3 \%$ & 1 & $16.7 \%$ & 6 & $100.0 \%$ & 11 \\
\hline Chile & 1 & $100.0 \%$ & 0 & $0.0 \%$ & 1 & $100.0 \%$ & 5 \\
\hline China & 0 & $0.0 \%$ & 2 & $100.0 \%$ & 2 & $100.0 \%$ & 13 \\
\hline Colombia & 1 & $100.0 \%$ & 0 & $0.0 \%$ & 1 & $100.0 \%$ & 0 \\
\hline Costa Rica & 2 & $100.0 \%$ & 0 & $0.0 \%$ & 2 & $100.0 \%$ & 0 \\
\hline Côte d'Ivoire & 2 & $100.0 \%$ & 0 & $0.0 \%$ & 2 & $100.0 \%$ & 0 \\
\hline Cuba & 16 & $45.7 \%$ & 19 & $54.3 \%$ & 35 & $100.0 \%$ & 13 \\
\hline Czech Republic & 1 & $50.0 \%$ & 1 & $50.0 \%$ & 2 & $100.0 \%$ & 5 \\
\hline Denmark & 2 & $66.7 \%$ & 1 & $33.3 \%$ & 3 & $100.0 \%$ & 0 \\
\hline Egypt & 11 & $57.9 \%$ & 8 & $42.1 \%$ & 19 & $100.0 \%$ & 8 \\
\hline France & 13 & $100.0 \%$ & 0 & $0.0 \%$ & 13 & $100.0 \%$ & 13 \\
\hline Germany & 1 & $100.0 \%$ & 0 & $0.0 \%$ & 1 & $100.0 \%$ & 11 \\
\hline Guatemala & 1 & $100.0 \%$ & 0 & $0.0 \%$ & 1 & $100.0 \%$ & 0 \\
\hline Hungary & 2 & $100.0 \%$ & 0 & $0.0 \%$ & 2 & $100.0 \%$ & 2 \\
\hline Indonesia & 1 & $100.0 \%$ & 0 & $0.0 \%$ & 1 & $100.0 \%$ & 13 \\
\hline Italy & 1 & $100.0 \%$ & 0 & $0.0 \%$ & 1 & $100.0 \%$ & 8 \\
\hline Japan & 4 & $100.0 \%$ & 0 & $0.0 \%$ & 4 & $100.0 \%$ & 13 \\
\hline Maldives & 2 & $100.0 \%$ & 0 & $0.0 \%$ & 2 & $100.0 \%$ & 0 \\
\hline Mexico & 9 & $100.0 \%$ & 0 & $0.0 \%$ & 9 & $100.0 \%$ & 13 \\
\hline Morocco & 1 & $100.0 \%$ & 0 & $0.0 \%$ & 1 & $100.0 \%$ & 0 \\
\hline Nigeria & 6 & $85.7 \%$ & 1 & $14.3 \%$ & 7 & $100.0 \%$ & 13 \\
\hline Norway & 3 & $100.0 \%$ & 0 & $0.0 \%$ & 3 & $100.0 \%$ & 2 \\
\hline Pakistan & 2 & $18.2 \%$ & 9 & $81.8 \%$ & 11 & $100.0 \%$ & 13 \\
\hline Palestine & 3 & $42.9 \%$ & 4 & $57.1 \%$ & 7 & $100.0 \%$ & 0 \\
\hline Poland & 0 & $0.0 \%$ & 1 & $100.0 \%$ & 1 & $100.0 \%$ & 5 \\
\hline Portugal & 8 & $88.9 \%$ & 1 & $11.1 \%$ & 9 & $100.0 \%$ & 0 \\
\hline President & 3 & $100.0 \%$ & 0 & $0.0 \%$ & 3 & $100.0 \%$ & - \\
\hline Russian Federation & 2 & $100.0 \%$ & 0 & $0.0 \%$ & 2 & $100.0 \%$ & 13 \\
\hline Slovakia & 1 & $100.0 \%$ & 0 & $0.0 \%$ & 1 & $100.0 \%$ & 5 \\
\hline Slovenia & 3 & $100.0 \%$ & 0 & $0.0 \%$ & 3 & $100.0 \%$ & 8 \\
\hline South Africa & 3 & $60.0 \%$ & 2 & $40.0 \%$ & 5 & $100.0 \%$ & 13 \\
\hline
\end{tabular}


Table 1 (continued)

\begin{tabular}{lrrrrrrr}
\hline Spain & 3 & $100.0 \%$ & 0 & $0.0 \%$ & 3 & $100.0 \%$ & 0 \\
Sweden & 1 & $100.0 \%$ & 0 & $0.0 \%$ & 1 & $100.0 \%$ & 0 \\
Switzerland & 1 & $100.0 \%$ & 0 & $0.0 \%$ & 1 & $100.0 \%$ & 0 \\
Thailand & 1 & $100.0 \%$ & 0 & $0.0 \%$ & 1 & $100.0 \%$ & 11 \\
Ukraine & 1 & $100.0 \%$ & 0 & $0.0 \%$ & 1 & $100.0 \%$ & 13 \\
United Kingdom of Great & & & & & & & 13 \\
Britain and Northern Ireland & 3 & $100.0 \%$ & 0 & $0.0 \%$ & 3 & $100.0 \%$ & 13 \\
Uruguay & 2 & $100.0 \%$ & 0 & $0.0 \%$ & 2 & $100.0 \%$ & 13 \\
Total & 146 & $3.7 \%$ & 52 & $26.3 \%$ & 198 & $100.0 \%$ & \\
\hline
\end{tabular}

these votes on resolutions ${ }^{33}$ plus some votes on amendments and motions (eight overall). This potential bias should be indirectly addressed when evaluating hypothesis 3, namely when considering how the authorship of the proposal voted upon affects the polarization of UNHRC members.

For our explanatory variables we rely on standard sources. To measure the respect for human rights we rely on Cingranelli and Richards' (2010) torture scale in 2008 as a general measure. As measure for democracy we rely on Cheibub et al. (2010) dichotomous coding for $2008 .{ }^{34}$ Finally, to have an assessment of the ratification behavior of UNHRC member states of human rights conventions we rely on Hathaway's (2007) data. The latter author provides for 2003 (and the years before) the ratification status of the major human rights convention. ${ }^{35}$ We used the number of these conventions ratified in 2003 (to allow for a sufficient lag) as measure as it takes some time for treaty ratifications to affect behavior.

In addition to these variables allowing us to evaluate our three hypotheses we also consider two control variables which might influence voting in the UNHRC. ${ }^{36}$ On the one hand we control for GDP per capita measured in 1995 PPP by relying on the Penn World Tables V7.0 (Heston et al. 2011). On the other we also use as control variable the Net Development Assistance and Aid (in constant USD) from the World Development Indicators (http://data.worldbank.org/data-catalog).

\footnotetext{
${ }^{33}$ We exclude from our analysis six resolutions adopted with no opposing votes. The six resolutions are the following ones: "Elimination of intolerance and discrimination based on religion or belief," "Role of good governance in the promotion and protection of Human Rights," "Mandate of special rapporteur on the promotion and protection of the rights of freedom and expression," "Torture and cruel treatment: the role of medical personnel," "Situation of human rights in the Democratic Republic of Congo," and "Right to development." See the online appendix on this journal's webpage for the full list of votes.

${ }^{34}$ For South Korea the 2008 coding is missing in this data. We coded this country as democracy. In a robustness check we also relied on the Polity indicator (Marshall et al. 2002).

${ }^{35}$ She covers the following treaties: 1987 Convention Against Torture and Other Cruel, Inhuman or Degrading Treatment (CAT), 1976 International Covenant on Civil and Political Rights (ICCPR), 1981 Convention on the Elimination of All Forms of Discrimination Against Women (CEDAW), Optional Protocol to the ICCPR, and Articles 21 and 22 to the CAT.

${ }^{36}$ Anonymous reviewers suggested these control variables, and we gratefully acknowledge these useful suggestions.
} 
Table 2 Proposer's identity and the EU's success

\begin{tabular}{|c|c|c|c|c|c|c|}
\hline \multirow[b]{2}{*}{ Outcome for EU } & \multicolumn{5}{|l|}{ Proposer } & \multirow[b]{2}{*}{ Total } \\
\hline & Pakistan & Cuba & Egypt & EU country & remaining & \\
\hline Loses & $78.3 \%(18)$ & $90.0 \%(18)$ & $57.1 \%(4)$ & $28.6 \%(2)$ & $46.2 \%(6)$ & $67.6 \%(48)$ \\
\hline Wins & $8.7 \%(2)$ & $10.0 \%(2)$ & $28.6 \%(2)$ & $71.4 \%(5)$ & $15.4 \%(2)$ & $19.7 \%(13)$ \\
\hline Abstains & $13.0 \%(3)$ & $0.0 \%(0)$ & $14.3 \%(1)$ & $0.0 \%(0)$ & $38.5 \%(5)$ & $12.7 \%(9)$ \\
\hline Total & $100.0 \%(23)$ & $100.0 \%(20)$ & $100.0 \%(7)$ & $100.0 \%(7)$ & $100.0 \%(13)$ & $100.0 \%(70)$ \\
\hline
\end{tabular}

\subsection{Model}

Analyses of voting decisions in assemblies carried out to understand what underlying conflict lines can be detected have made considerable advances, also when it comes to studies on international bodies. Early work, for instance by Alker (1964) (see also Alker \& Russett 1965) largely employed factor analytic models to determine the underlying conflict lines. As scholars mostly dealing with the US congress noted, such factor analytic models lack, however, a solid theoretical underpinning to allow for generating information on the relevant conflict lines. Based on this critique Poole and Rosenthal (1985) developed a theoretically informed estimator based on a spatial model of decision making. ${ }^{37}$ This estimation procedure, called NOMINATE, was used among others by Voeten (2000) in his study on voting in the UNGA. More recently scholars proposed estimating the underlying conflict lines by relying on the so-called item-response theory (IRT) model stemming from the school testing literature (e.g., Fox 2010). Clinton et al. (2004) propose this approach to estimate the ideal-points of legislators (see also Jackman 2004; Gelman \& Hill 2006). ${ }^{38}$ All these models rely on parametric models with quite constraining assumptions underlying the estimator. Poole (2000) thus proposes a nonparametric technique to estimate idealpoints of legislators. ${ }^{39}$ In some recent critical articles Spirling and McLean (2006, 2007) alert the reader that under certain circumstances these estimators may fail to yield meaningful estimates, namely if the assumed spatial model of voting is not appropriate, for instance if government and opposition vote against each other and the latter are dispersed on opposite sides on the ideological scale.

All these methods have been applied to voting in international bodies in order to deduce the preferences of member states based on their spatial location (for instance after a factor analysis). If states belonging to particular blocs appeared to be located close to each other "bloc voting" was induced. This inductive approach is

\footnotetext{
${ }^{37}$ See, however, Heckman and Snyder's (1997) proposal how a simple linear probability model might be underlying a factor analytic estimation procedure (though see Poole 2005).

${ }^{38}$ Carroll et al. (2009) offer an empirical evaluation of these different estimators.

${ }^{39}$ These various techniques are discussed in detail in Poole (2005).
} 
unsatisfactory as "blocs" are inferred from similar voting patterns, even though they might also simply be due to similar preferences. In the approach we propose preferences are estimated based on voting patters but also linked to explanatory factors of these preferences. In addition, we also estimate how bloc-membership constrains the voting patterns of their members beyond the variables that we hypothesize affect preferences.

These external sources of information can easily be taken into account when estimating models, especially those based on the item-response theory as estimated in a Bayesian framework. For instance, Høyland and Hansen (2010) employ additional information on preferences to assess whether in the Council of Ministers of the European Union a push toward more consensus exists. Similarly, Malecki (2008) proposes, based on work by Fox and Glas (2001) (see also Fox 2007, 2010, 141-192), a hierarchical item-response theory model, where the ideal-points are "explained" in part by exogenous variables. ${ }^{40}$ Gabel et al. (2008) use this approach to assess what elements affect voting behavior on the European parliament (EP), while Høyland (2010), drawing on a suggestion by Clinton et al. (2004), studies how party group pressure is exerted in legislative matters in the EP, compared to votes on non-legislative matters. ${ }^{41}$

In our study of the UNHRC we also rely on the classic "two-parameter" itemresponse theory (IRT) model. In this model the probability $\left(\pi_{i j}\right)$ of a yes-vote $\left(y_{i j}\right)$ by actor $i$ on issue $j$ is following Jackman $(2009,455)$

$$
\begin{aligned}
\pi_{i j} & =\operatorname{Pr}\left(y_{i j} \mid \theta_{i}, \beta_{j}, \alpha_{j}\right) \\
& =F\left(\theta_{i} \beta_{j}-\alpha_{j}\right)
\end{aligned}
$$

where $\theta_{i}$ is in our context the revealed ideal-point, $\beta_{j}$ the item discrimination of issue $j$ and $\alpha_{j}$ the item difficulty of issue $j . F$ being a cumulative density function either of a normal or logistic type. For identification purposes, $\theta_{i}$ is usually assumed to be normally distributed with $\mu_{\theta}=0$ and $\sigma_{\theta}^{2}=1$.

Fox and Glas (2001) (see also Fox 2007, 2010, 141-192) present the basic ideas how an IRT model may accommodate a hierarchical data structure. Based on this Malecki (2008) models $\theta$ as being dependent on some person specific characteristics. When addressing the issue what member countries of the UNHRC vote together we adopt such a hierarchical IRT model allowing the $\theta$ s to vary systematically with characteristics of the member states $\left(x_{i}\right)$. More precisely we assume that

$$
\theta_{i}=x_{i} \beta_{\theta}+\epsilon_{\theta}
$$

\footnotetext{
${ }^{40}$ See for a similar approach to address a different problem Lauderdale's (2010) hierarchical item-response theory model.

${ }^{41}$ Proceeding in a more traditional way by estimating in a panel framework a model trying to explain individual voting decisions would not allow us to take into account both preferences and bloc membership in addition to information on who proposed the resolution voted upon.
} 
In a second step we assume that the item discrimination parameter $\beta_{j}$ varies with characteristics of the resolution voted upon, more specifically its authorship $\left(x_{j}\right) .{ }^{42}$ For this we assume that

$$
\beta_{j}=x_{j} \beta_{\beta}+\epsilon_{\beta}
$$

IRT models are most frequently estimated in a Bayesian framework, given the numerous parameters to estimate and the distributional assumptions required for identification. We proceed similarly in this framework and implemented these models in JAGS (Plummer 2010). ${ }^{43}$

\section{Empirical results}

As only 76 votes occurred in the first thirteen sessions of the United Nations Human Rights Council, we rely on a rather small empirical basis. In addition, as noted above, we drop six unanimous votes from our analysis, as they are uninformative for the estimates we wish to provide. ${ }^{44}$ This leaves us with 70 votes and 64 members who voted in part in these votes. Each of the 64 member states voted on at least 9 of these topics. We use this empirical base to evaluate our hypotheses, as discussed above, with a hierarchical IRT-model. This model estimates at the same time the revealed "ideal-points" (or preferences) for the member states, but also how the latter are influenced by various independent variables (among them bloc-membership and variables related to preferences). While voting in the UNHRC is ternary, namely comprising yes- and no-votes as well as abstentions, we focus our analysis only on the first two alternatives. Proceeding like this is justified, as the rules of procedure (http://ap. ohchr.org/documents/E/HRC/resolutions/A_HRC_RES_5_1.doc) clearly specify that with very few exceptions, abstentions are not relevant for the voting outcome, as decisions are reached by simple majority by the member states present and voting. Consequently, abstentions are likely to follow a different pattern and can hardly be conceived as some intermediary category (though see Voeten 2004; Boockmann \& Dreher 2011).

As discussed above, our hypotheses relate to the effect of membership in two groups, on the one hand, and democracy, human rights records and ratification of human rights treaties on the other. Table 3 reports the second-level estimates of two IRT models in which we first only estimate the parameters in Eqs. 1 and 2 and then

\footnotetext{
${ }^{42}$ Estimating these effects together with effects of blocs and preferences on voting requires an IRT-model as used here. Using a more traditional type of regression model would require us to manually recode all votes to ensure that our independent variables have the same directional effect in all votes. Our IRT-model directly estimates the relevant "direction," allows for estimating all the relevant parameters in one single model and in addition imputes the missing data for the dependent variable (i.e., the votes).

${ }^{43}$ In an earlier version of this paper we also relied for the simpler models on Malecki's (2008) implementation of hierarchical IRT-models in MCMCpack (Martin and Quinn 2004).

${ }^{44}$ See the online appendix on this journal's webpage for the full list of votes considered.
} 
Table 3 Hierarchical IRT model: second-level estimates

\begin{tabular}{|c|c|c|c|c|c|c|}
\hline \multirow[b]{2}{*}{ Variable } & \multirow[b]{2}{*}{$\mathrm{b}$} & \multicolumn{2}{|c|}{ Credible interval } & \multirow[b]{2}{*}{$\mathrm{b}$} & \multicolumn{2}{|c|}{ Credible interval } \\
\hline & & $2.5 \%$ & $97.5 \%$ & & $2.5 \%$ & $97.5 \%$ \\
\hline Democracy & 0.397 & -0.355 & 1.150 & -0.322 & -1.060 & 0.439 \\
\hline \multicolumn{7}{|l|}{ Torture } \\
\hline Often & -0.852 & -1.650 & -0.052 & 0.894 & 0.064 & 1.705 \\
\hline Frequently & -1.630 & -2.529 & -0.795 & 1.675 & 0.753 & 2.540 \\
\hline $\mathrm{EU}$ & 0.906 & 0.057 & 1.766 & -0.836 & -1.658 & -0.036 \\
\hline OIC & -1.586 & -2.441 & -0.723 & 1.600 & 0.825 & 2.535 \\
\hline Ratification & 0.011 & -0.162 & 0.203 & 0.007 & -0.169 & 0.188 \\
\hline GDP & 0.017 & -0.008 & 0.040 & -0.015 & -0.038 & 0.008 \\
\hline Aid & 0.012 & -0.196 & 0.208 & -0.016 & -0.221 & 0.199 \\
\hline Proposer: EU & & & & -11.402 & -18.370 & -5.505 \\
\hline Pakistan & & & & 2.571 & -1.658 & 8.455 \\
\hline Cuba & & & & 18.095 & 6.068 & 32.848 \\
\hline Egypt & & & & 5.893 & -2.653 & 15.314 \\
\hline$\mu_{\beta}$ & -7.186 & -11.783 & -4.293 & 4.952 & 0.872 & 9.378 \\
\hline$\mu_{\alpha}$ & -3.759 & -6.129 & -2.146 & -4.696 & -7.762 & -2.414 \\
\hline$\sigma_{\beta}$ & 0.024 & 0.007 & 0.054 & 0.032 & 0.010 & 0.076 \\
\hline$\sigma_{\alpha}$ & 0.131 & 0.045 & 0.306 & 0.066 & 0.024 & 0.150 \\
\hline Deviance & 210.768 & 175.899 & 249.600 & 192.820 & 162.071 & 226.274 \\
\hline $\mathrm{n}$ votes & 70 & & & 70 & & \\
\hline $\mathrm{n}$ legislators & 64 & & & 64 & & \\
\hline
\end{tabular}

also integrate Eq. 3 in the second model. ${ }^{45}$ The estimates (with their respective credible intervals) suggest that all our hypotheses point in the right direction. Considering hypothesis 1 related to the effect of belonging to a particular bloc, we find that the EU and the OIC pull their member countries in opposite directions from the remaining UNHRC member-states. The credible intervals for both of these effects fail to comprise the value of zero. Consequently, we have quite considerable evidence that belonging to one of these two blocs actually influences systematically the voting behavior of UNHRC members.

Regarding our second hypothesis both models reported upon in Table 3 offer considerable support that preferences as measured by our three variables influence the voting in the UNHRC. Countries engaging often or frequently in torture vote systematically differently from those not engaging in torture. Democracies and countries

\footnotetext{
${ }^{45}$ In the online appendix we depict some convergence diagnostics for all parameters estimated in the model. Most parameter distributions seem to have converged (except the $\theta$ s of some member states that have voted only infrequently) after the 50000 burn-in iterations. Hence the reported estimates characterize 5000 iterations thinned by 5 .
} 
having ratified more human rights treaties appear to vote in the opposite direction, but the credible intervals for these two variables include the value of zero. Regarding our two control variables we also fail to find any systematic effect. Receiving development aid and/or being a rich or poor country fails to affect the preferences that find expression in UNHRC voting. Thus it seems that the preferences emerging in this assembly are related mostly to human rights practices, lending support to our second hypothesis.

Our first model reported upon in Table 3, however, is clearly too simple, especially given our results showing that the proposers of resolutions affect the results from the EU's perspective. To assess this and evaluate our third hypothesis we estimate a second hierarchical IRT-model, this time with the parameter for the item discrimination $(\beta)$ varying as a function of the proposer's identity, thus estimating the parameters in Eqs. 1, 2, and 3. For simplicity's sake we categorize the proposers into four groups, namely the ones used in Table 2 . As base category we employ the residual category of "remaining" proposers. Consequently the estimated parameters reported for the second model in Table 3 indicate whether resolutions proposed for instance by EU member countries, discriminate more or less strongly among council members than resolutions by the remaining countries. ${ }^{46}$ Similarly the sign indicates whether the yes and no votes are on the same sides as in votes on resolutions proposed by the remaining countries or not.

The results reported for model 2 in Table 3 underline again the crucial role played by Cuba in controversial votes. Resolutions proposed by this country discriminate most strongly among council members and compared with those proposed by other countries and the credible intervals for this effect excludes the value of 0 . The direction of the effect is similar for resolutions proposed by Egypt and Pakistan, though the credible intervals for these coefficients are large and comprise 0 . The coefficient for the EU is positive, suggesting that resolutions introduced by EU member states are on average less discriminating than those of the remaining UNHRC members. The credible interval for this coefficient is large, however, and comprises 0 , implying that we cannot distinguish this effect from a null-effect.

When considering the estimated coefficients for blocs and our preference variables we find largely the same results as above. Figure 1 illustrates the effects estimated for our second model graphically with their respective credible intervals based on the second model in Table $3{ }^{47}$ The figure clearly provides support for our first hypothesis. The EU member states vote quite distinctly from their fellow UNHRC members, as do the members of the OIC though in another direction. Consequently, our results

\footnotetext{
${ }^{46}$ In the online appendix we depict some convergence diagnostics for all parameters estimated in the model. Convergence for this model is more problematic even after 50000 burn-in iterations. Nevertheless we report estimates that characterize the 5000 iterations thinned by 5 .

${ }^{47}$ We refrain from depicting the results graphically as some of the credible intervals are very large and would distort a figure. In the online appendix we depict again some convergence diagnostics for all parameters estimated in the model. Most parameter distributions seem to have converged but some, especially those based on few data points, hardly converged after the 1000000 burn-in iterations. The reported estimates characterize 5000 iterations thinned by 5 after the burn-in iterations.
} 


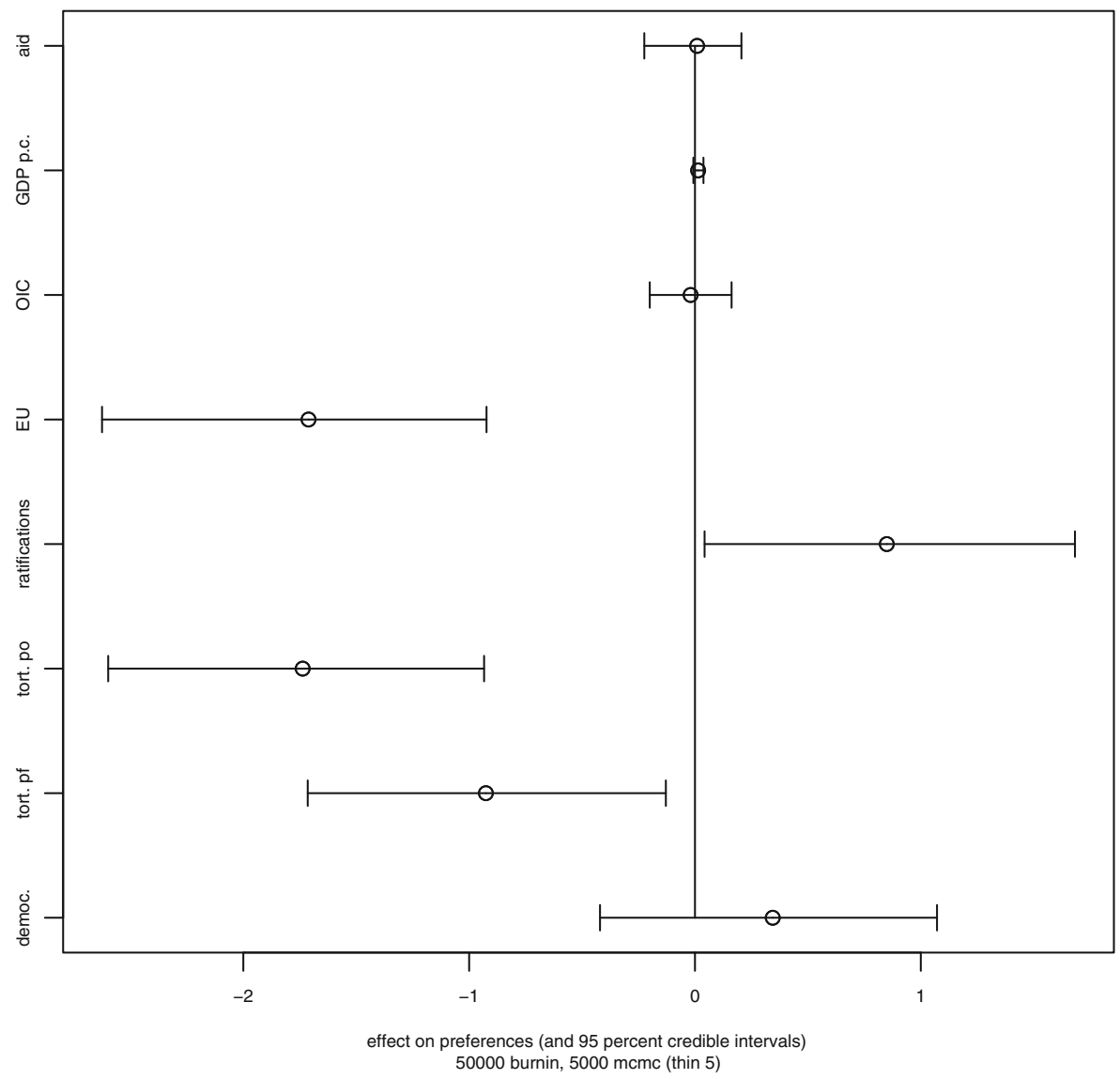

Fig. 1 Hierarchical IRT Model: mean estimates of second-level coefficients for preferences and credible intervals

lend support to studies on the EU, like Young and Rees (2005), Smith (2006) and Wouters et al. (2008), who document an important coordination effort among the member states. The same also appears for the OIC, for which Besant and Malo (2009, 145) also highlight the considerable coordination work. The effects are even stronger for our main preference variable, namely whether countries engage in torture or not.

To have more confidence in our results we reestimated our two models by replacing our two central variables linked to preferences by other measures. ${ }^{48}$ Instead of using Cingranelli and Richards' (2010) torture scale we relied on the "Political Terror Scale" (Wood and Gibney 2010). We also replaced Cheibub et al.'s (2010) dichotomous measure of democracy with the 21 point scale provided by the Polity

\footnotetext{
${ }^{48}$ This was suggested by reviewers, and we gratefully acknowledge this useful suggestion.
} 
Table 4 Hierarchical IRT model: second-level estimates, robustness check

\begin{tabular}{|c|c|c|c|c|c|c|}
\hline \multirow[b]{2}{*}{ Variable } & \multirow[b]{2}{*}{$\mathrm{b}$} & \multicolumn{2}{|c|}{ Credible interval } & \multirow[b]{2}{*}{$\mathrm{b}$} & \multicolumn{2}{|c|}{ Credible interval } \\
\hline & & $2.5 \%$ & $97.5 \%$ & & $2.5 \%$ & $97.5 \%$ \\
\hline Democracy: polity2 & -0.068 & -0.149 & 0.006 & -0.070 & -0.156 & 0.008 \\
\hline Political terror scale 2 & 0.695 & -0.109 & 1.456 & 0.797 & 0.002 & 1.633 \\
\hline 3 & 1.361 & 0.611 & 2.155 & 1.505 & 0.689 & 2.320 \\
\hline 4,5 & 2.394 & 1.388 & 3.433 & 2.512 & 1.536 & 3.641 \\
\hline $\mathrm{EU}$ & -0.790 & -1.676 & 0.057 & -0.721 & -1.633 & 0.190 \\
\hline OIC & 1.384 & 0.459 & 2.373 & 1.420 & 0.441 & 2.462 \\
\hline Ratification & 0.002 & -0.193 & 0.199 & 0.038 & -0.166 & 0.232 \\
\hline GDP & -0.009 & -0.034 & 0.018 & -0.004 & -0.030 & 0.023 \\
\hline Aid & -0.071 & -0.287 & 0.161 & -0.051 & -0.272 & 0.200 \\
\hline Proposer: EU & & & & -7.046 & -11.910 & -0.969 \\
\hline Pakistan & & & & 2.406 & -0.629 & 6.114 \\
\hline Cuba & & & & 12.385 & 4.916 & 22.615 \\
\hline Egypt & & & & 4.497 & -0.544 & 10.0159 \\
\hline$\mu_{\beta}$ & 6.827 & 3.831 & 11.921 & 3.010 & 0.382 & 6.063 \\
\hline$\mu_{\alpha}$ & -3.759 & -5.879 & -2.251 & -3.540 & -5.647 & -1.978 \\
\hline$\sigma_{\beta}$ & 0.028 & 0.008 & 0.067 & 0.077 & 0.025 & 0.198 \\
\hline$\sigma_{\alpha}$ & 0.134 & 0.043 & 0.292 & 0.110 & 0.040 & 0.236 \\
\hline Deviance & 210.262 & 175.642 & 248.835 & 209.543 & 176.674 & 248.778 \\
\hline $\mathrm{n}$ votes & 70 & & & 70 & & \\
\hline $\mathrm{n}$ legislators & 64 & & & 64 & & \\
\hline
\end{tabular}

indicator (Marshall et al. 2002). ${ }^{49}$ The results depicted in Table 4 clearly demonstrate the robustness of our results regarding preferences (i.e., hypothesis 2). We still find a considerable effect for our main variable related to preferences, namely the "Political Terror Scale." These effects are particularly clear when we control for the authorship of the resolution voted upon (model 2). Similarly, in this second model we also find that the credible interval for our democracy measure excludes the value of 0 , suggesting that there is a systematic effect of this variable on the voting behavior of UNHRC members. The effect of this variable, however, is rather small (see also Fig. 2).

While thus the robustness check strengthens our confidence in hypothesis 2, the results depicted in Table 4 suggest that hypothesis 1 is on much less solid ground.

\footnotetext{
${ }^{49}$ For these two variables we have two cases with missing data. For the "Political Terror Scale" based on US State Department reports the value for the US is missing. As the score based on Amnesty International reports equals 2, we used this value. Similarly, according to the Polity website the Polity2 value for Bosnia Herzegovina is equal to 5 , so we used this value.
} 


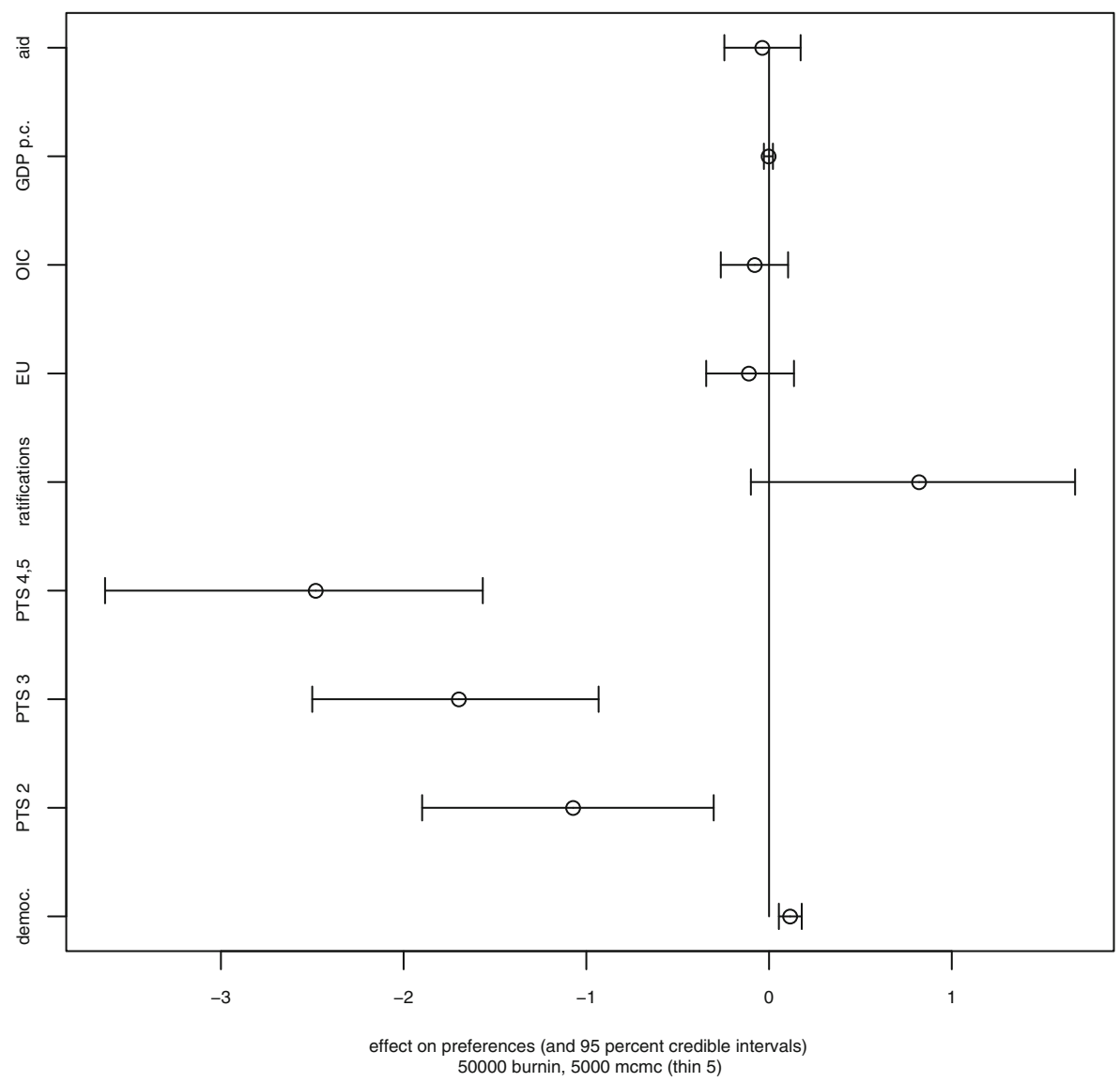

Fig. 2 Hierarchical IRT Model: mean estimates of second-level coefficients for preferences and credible intervals (robustness test)

While in model 1 we still find a considerable effect for OIC bloc-membership, the credible interval for the EU fails to exclude the value of 0 . In model 2 this is even the case for both blocs, suggesting that bloc-membership does not systematically affect voting behavior in the UNHRC. Regarding the control variables we still fail to find a systematic effect, both in models 1 and 2 . Our results regarding the influence of Cuba as a proposer of resolutions survives this robustness check as well (model 2).

We depict the effects related to hypotheses 1 and 2 again graphically in Fig. 2. This figure shows that support for hypothesis 2 , namely that variables related to preferences affect voting in the UNHRC, is quite robust and solid. On the other hand, it appears that the effect of bloc-membership is not as robust, as it depends on whether or not we control for the authorship of resolutions, and on what preference variables we employ. Support for hypothesis 1, taking into account Fig. 2, 
is thus weaker. Quite to the contrary, the two sets of analyses lend considerable support to hypothesis 3 related to the effect of authorship of resolutions those resolutions authored by Cuba appear to discriminate more strongly among UNHRC members.

\section{Conclusion}

Our systematic analysis of controversial votes in the UNHRC suggests that voting behavior is largely affected by what we might consider the preferences of member states. Despite controlling for the major human rights relevant "peer groups" we find that their effects pale compared to those of variables related to preferences. Consequently, both the human rights record of a country and to a lesser extent its level of democracy prove important factors in explaining the preferences related to voting in the UNHRC. Countries with poor human rights records vote systematically differently from those that do not engage in torture.

On the other hand we find only mixed evidence that blocs are relevant in this new UN institution. Whether we find evidence in support of bloc-voting depends on the measures we use for our preference variables and whether we control for the authorship of the resolution voted upon. Here we find that resolutions proposed by Cuba strongly polarize the member states of the UNHRC in their voting.

While our analyses are still based on a rather limited empirical basis, we can draw two broad conclusions. First of all, from a methodological perspective our analysis demonstrates that work on international assemblies should employ approaches that allow to distinguish between the effects of blocs and preferences when looking at voting behavior. When doing so, accounting for the authorship of the proposals also proves important. Second, from a substantive point of view our analyses suggest that the criticisms leveled against the UNHRC's predecessor have not lost all their relevance. When assessing the effect of a resolution's sponsor we find that especially one set of resolutions can be distinguished. Those proposed by Cuba heavily discriminate among members of the UNHRC and thus find strong reflection in the voting patterns. They differ from proposals submitted by other countries, especially compared to those authored by EU member countries. The latter countries also systematically lose in the controversial votes initiated by Cuba, and to a lesser extent by Egypt and Pakistan.

Hence our results suggest that not all defects of the UNCHR have been mended with the UNHRC. ${ }^{50}$ Controversy in this assembly is largely introduced by countries with blemished human rights records. As a consequence, many of the conclusions presented on the UNHRC's predecessor still seem to apply. Hence, despite a heavy dose of "lipstick" the animal has not lost all its "caterpillar"-features.

\footnotetext{
${ }^{50} \mathrm{Hug}$ (2013) can show that in the last ten sessions of the UNCHR Cuba was the second most frequent proposer of resolutions, following the United States (the latter country not being a member of the UNHRC at its beginning).
} 


\section{References}

Alker, H.R. (1964). Dimensions of conflict in the general assembly. American Political Science Review, 58(3), 642-657.

Alker, H.R., \& Russett, B. (1965). World politics in the general assembly. New Haven: Yale University Press.

Attina, F. (1990). The voting behaviour of European parliament members and the problem of the Europarties. European Journal of Political Research, 18, 557-579.

Ball, M. (1951). Bloc voting in the general assembly. International Organization, 5(1), 3-31.

Besant, A., \& Malo, S. (2009). Dim prospects for the United Nations Human Rights Council. Yale Journal of International Affairs, 2(2), 144-148.

Boockmann, B. (2003). Mixed motives: an empirical analysis of ILO roll-call voting. Constitutional Political Economy, 14(4), 263-285.

Boockmann, B. (2006). Participation and voting in committees: evidence from the ILO. Public Choice, 126, 405-427.

Boockmann, B., \& Dreher, A. (2011). Do human rights offenders oppose human rights resolutions in the United Nations? Public Choice, 146, 443-467.

Brzinski, J.B. (1995). Political group cohesion in the European Parliament, 1989-1994. In C. Rhodes, \& S. Mazey (Eds.), The state of the European union (pp. 135-158). London: Longman.

Carey, S.C., Gibney, M., Poe, S.C. (2010). The politics of human rights. New York: Cambridge University Press.

Carroll, R., Lewis, J.B., Lo, J., Poole, K.T., Rosenthal, H. (2009). Comparing NOMINATE and IDEAL: points of difference and Monte Carlo tests. Legislative Studies Quarterly, 34(4), 555-591.

Carrubba, C.J., Gabel, M., Hug, S. (2008). Legislative voting behavior, seen and unseen: adjusting for selection effects in roll call vote analysis. Legislative Studies Quarterly, 33(4), 543-572.

Cheibub, J., Gandhi, J., Vreeland, J. (2010). Democracy and dictatorship revisited. Public Choice, 143, $67-101$.

Cingranelli, D.L., \& Richards, D.L. (2010). The Cingranelli and Richards (CIRI) human rights data project. Human Rights Quarterly, 32, 401-424.

Clinton, J.D., Jackman, S., Rivers, D. (2004). The statistical analysis of roll call voting: a unified approach. American Political Science Review, 98(2), 355-370.

Cox, E. (2010). State interest and the creation and functioning of the United Nations Human Rights Council. Journal of International Law and International Relations, 6(1), 87-120.

Dreher, A., Sturm, J.-E., Vreeland, J. (2009). Global horse trading: IMF loans for votes in the United Nations Security Council. European Economic Review, 53, 742-757.

Edwards, M.S., Scott, K.M., Allen, S.H., Irvin, K. (2008). Sins of commission? Understanding membership patterns on the United Nations Human Rights Commission. Political Research Quarterly, 61(3), $390-402$.

Fox, J.-P. (2007). Multilevel IRT modeling in practice with the package mlirt. Journal of Statistical Software, 20(5), 1-16.

Fox, J.-P. (2010). Bayesian item response modeling: theory and applications. Springer, New York.

Fox, J.-P., \& Glas, C.A.W. (2001). Bayesian estimation of a multilevel IRT model using Gibbs sampling. Psychometrika, 66, 271-288.

Furey, J.B. (1954). Voting alignment in the general assembly. Doctoral Dissertation, Columbia University, New York (Publication 6620, Ann Arbor, University Microfilms).

Gabel, M.J., Hix, S., Malecki, M. (2008). From preferences to behavior: modeling MEPs? Roll-call voting behavior. Paper prepared for presentation at Midwest Political Science Association Annual Meeting, 4-7 April.

Gelman, A., \& Hill, J. (2006). Data analysis using regression and multilevel/hierarchical models. New York: Cambridge University Press.

Hathaway, O.A. (2002). Do human rights treaties make a difference? Yale Law Journal, 111, 1935-2042.

Hathaway, O.A. (2007). Why do countries commit to human rights treaties? Journal of Conflict Resolution, 51(4), 588-621.

Heckman, J.J., \& Snyder Jr., J.M. (1997). Linear probability models of the demand for attributes with an empirical application to estimating the preferences of legislators. The Rand Journal of Economics, 28(special issue), S142-S189. 
Henderson, C.W. (1991). Conditions affecting the use of political repression. Journal of Conflict Resolution, 35(1), 120-142.

Heston, A., Summers, R., Aten, B. (2011). Penn world table version 7.0. Center for International Comparisons of Production, Income and Prices at the University of Pennsylvania.

Hillman, A.L., \& Potrafke, N. (2011). Voting in the absence of ethical restraint: decoys and dissonance in the United Nations. Paper prepared for presentation at the conference The Political Economy of International Organizations, ETH and University Zurich, January.

Hix, S., Noury, A., Roland, G. (2006). Democratic politics in the European Parliament. Cambridge: Cambridge University Press.

Holloway, S. (1990). Forty years of United Nations General Assembly voting. Canadian Journal of Political Science, 23(2), 279-296.

Hollyer, J.R., \& Rosendorff, P. (2011). Domestic politics and the accession of authoritarian regimes to human rights treaties. Quarterly Journal of Political Science, 6(3-4), 275-327.

Hovet, T. (1960). Bloc politics in the United Nations. Cambridge: Harvard University Press.

Høyland, B. (2010). Procedural and party effects in European Parliament roll call votes. European Union Politics, 11(4), 597-613.

Høyland, B., \& Hansen, V.W. (2010). Voting in the consensual council of ministers. Paper prepared for presentation at the ECPR Fifth Pan-European Confereence, Porto, 24-26 June 2010.

Hug, S. (2010). Selection effects in roll call votes. British Journal of Political Science, 40(1), 225-235.

Hug, S. (2012). What's in a vote? Paper prepared for presentation at the 5th Conference on The Political Economy of International Organizations, Villanova, January.

Hug, S. (2013). Dealing with human rights in international organizations. Paper prepared for presentation at the 6th Conference on The Political Economy of International Organizations, Mannheim/Heidelberg, February.

Jackman, S. (2004). Bayesian analysis for political research. Annual Review of Political Science, 7, 483505.

Jackman, S. (2009). Bayesian analysis for the social sciences. New York: Wiley.

Krehbiel, K. (1993). Where's the party? British Journal of Political Science, 23(2), 235.

Lauderdale, B.E. (2010). Unpredictable voters in ideal point estimation. Political Analysis, 18, 151-171.

Lebovic, J.H., \& Voeten, E. (2006). The politics of shame: the condemnation of country human rights practices in the UNCHR. International Studies Quarterly, 50(4), 861-888.

Lebovic, J.H., \& Voeten, E. (2009). The cost of shame: international organizations and foreign aid in the punishing of human rights violators. Journal of Peace Research, 46(1), 79-97.

Lijphart, A. (1963). The analysis of bloc voting in the general assembly: a critique and a proposal. American Political Science Review, 57(4), 902-917.

Luif, P., \& Radeva, M. (2007). EU co-ordination in international organizations: the case of the United Nations General Assembly and the Organization for Security and Co-operation in Europe. In N. Casarini, \& C. Musu (Eds.), European foreign policy in an evolving international system. The road towards convergence (pp. 27-40). Basingstoke: Palgrave.

Lukács, R. (2010). Voting patterns in the United Nation Human Rights Council. Seminar paper, Master en science politique, Université de Genève.

Lukács, R. (2011). Human rights cooperation or a playground for human rights violators? Voting behavior in the United Nations Human Rights Council. Master's thesis in political science, Université de Genève.

Macaj, G., \& Koops, J.A. (2012). Inconvenient multilateralism: the challenges of the EU as a player in the United Nations Human Rights Council. In J. Wetzel (Ed.), The EU as a global player in human rights? (pp. 71-86). London: Routledge.

Malecki, M. (2008). MCMCirtHierld: subject-specific covariates implemented in MCMCpack. Poster presented at Society for Political Methodology Summer Meeting, 9-12 July.

Marin-Bosch, M. (1987). How nations vote in the general assembly of the United Nations. International Organization, 41, 705-724.

Marshall, M.G., Gurr, T., Davenport, C., Jaggers, K. (2002). Polity IV, 1800-1999: a reply to Munck and Verkuilen. Comparative Political Studies, 35(1), 40-45.

Martin, A.D., \& Quinn, K.M. (2004). MCMCpack 0.4-8. Available from http://mcmcpack.wustl.edu.

McMahon, E.R. (2012). Assessing the first cycle of the UN Human Rights council universal periodic review: herding cats and sheep. Paper prepared for presentation at the Annual Meeting of the Midwest Political Science Association, Chicago, 12-15 April 2012. 
Meyers, B.D. (1966). African voting in the United Nations General Assembly. The Journal of Modern African Studies, 4(2), 213-227.

Neumayer, E. (2005). Do international human rights treaties improve respect for human rights? Journal of Conflict Resolution, 49(6), 925-953.

Newcombe, H., Ross, M., Newcombe, A.G. (1970). United Nations voting patterns. International Organization, 24, 100-121.

Nicholas, H.G. (1962). The United Nations as a political institution, 2nd edn. Oxford: Oxford University Press.

Ogley, R.C. (1961). Voting and politics in the general assembly. International Relations, 2(3), 156-167.

O'Neill, B. (1996). Power and satisfaction in the United Nations Security Council. The Journal of Conflict Resolution, 40(2), 219-237.

Park, H.S. (1987). Correlates of human rights: global tendencies. Human Rights Quarterly, 9(3), 405-413.

Plummer, M. (2010). JAGS version 2.1.0 user manual. International Agency for Research on Cancer Infection and Cancer Epidemiology (ICE) group.

Poe, S.C., \& Tate, C.N. (1994). Repression of human rights to personal integrity in the 1980s: a global analysis. American Political Science Review, 88(4), 853-872.

Poole, K. (2000). Nonparametric unfolding of binary choice data. Political Analysis, 8(3), 211-237.

Poole, K. (2005). Spatial models of parliamentary voting. New York: Cambridge University Press.

Poole, K., \& Rosenthal, H. (1985). A spatial model for legislative roll call analysis. American Journal of Political Science, 29, 357-384.

Rajagopal, B. (2007). Lipstick on a caterpillar? Assessing the new U.N. Human Rights Council through historical reflection. Buffalo Human Rights Law Review, 13(7).

Riggs, R.E. (1958). Politics in the United Nations, a study of United States influence in the general assembly. Illinois Studies in the Social Sciences, 41, 21-27.

Seligman, S. (2011). Politics and principle at the UN Human Rights Commission and Council (19922008). Israel Affairs, 17(4), 520-541.

Simmons, B.A. (2009). Mobilizing for human rights: international law in domestic politics. New York: Cambridge University Press.

Smith, K.E. (2006). Speaking with one voice? European Union co-ordination on human rights issues at the United Nations. Journal of Common Market Studies, 44(1), 113-137.

Smith, K.E. (2010). The European Union at the human rights council: speaking with one voice but having little influence. Journal of European Public Policy, 17(12), 224-241.

Spirling, A., \& McLean, I. (2006). The rights and wrongs of roll calls. Government and Opposition, 41(4), 581-588.

Spirling, A., \& McLean, I. (2007). UK OC OK? Interpreting optimal classification scores for the U.K. House of Commons. Political Analysis, 15(1), 85-96.

Steinberg, G.M. (2012). From Durban to the Goldstone report: the centrality of human rights NGOs in the political dimension of the Arab? Israeli conflict. Israel Affairs, 18(3), 372-388.

Tolley, H. (1987). The U.N. commission on human rights. Boulder: Westview Press.

Voeten, E. (2000). Clashes in the assembly. International Organization, 54(2), 185-215.

Voeten, E. (2004). Resisting the lonely superpower: responses of states in the UN to U.S. dominance. Journal of Politics, 66(3), 729-754.

Vreeland, J.R. (2008). Political institutions and human rights: why dictatorships enter into the United Nations convention against torture. International Organization, 62(1), 65-101.

Wood, R.M., \& Gibney, M. (2010). The political terror scale (PTS): a re-introduction and a comparison to CIRI. Human Rights Quarterly, 32, 367-400.

Wouters, J., Basu, S., Bernaz, N. (2008). The role of the European Union in the human rights council. EIUC - European Inter University Centre.

Young, H., \& Rees, N. (2005). EU voting behaviour in the UN General Assembly, 1990-2002: the EU's Europeanising tendencies. Irish Studies in International Affairs, 16, 193-207. 